International Journal of Forensic Science \& Pathology (IJFP)

ISSN 2332-287X

\title{
Wildlife DNA Forensic in Curbing Illegal Wildlife Trade: Specie Identification from Seizures
}

\section{Case Report}

Ved P. Kumar ${ }^{1,2 *}$, Dhyanendra Kumar', Surendra P. Goyal ${ }^{1}$

${ }^{1}$ Wildlife Institute of India, Post Box \# 18, Chandrabani, Dehradun 248001, Uttarakhand, India.

${ }^{2}$ Veer Kunwar Singh University, Arrah 802301, Bihar, India.

\section{Abstract}

Species identification in wildlife forensics is the one of the major concern to enforce law and curbing illegal wildlife trade. Among all the available analytical teqniques DNA based species identification is the most robust and acceptable evidence in the court of law. We analysed cytochrome $b$ and $12 \mathrm{~S}$ rRNA mtDNA fragments to identify species from three different seizures. DNA based analysis of Cyt $\mathrm{b}$ and $12 \mathrm{~S}$ rRNA has identified three seizures as Hog deer, Chital and Swamp deer.

Keywords: PCR Amplification; Cytochrome b; 12s rRNA; Wildlife.

\section{*Corresponding Author:}

Ved P. Kumar

Wildlife Institute of India, Post Box \# 18, Chandrabani, Dehradun 248001, Uttarakhand, India.

Tel: +91-135-2640112-117 X 235; Fax: + 91-135-2640115

E-mail:vpt@wii.gov.in

Received: April 29, 2014

Accepted: June 06, 2014

Published: June 11, 2014

Citation: Ved P. Kumar, Dhyanendra Kumar, Surendra P. Goyal (2014) Wildlife DNA Forensic in Curbing Illegal Wildlife Trade: Species Identification from Seizures. Int J Forensic Sci Pathol. 2(5), 38-42. doi: http:/ / dx.doi.org/10.19070/2332-287X-1400012

Copyright: Ved P. Kumar ${ }^{\circ}$ 2014. This is an open-access article distributed under the terms of the Creative Commons Attribution License, which permits unrestricted use, distribution and reproduction in any medium, provided the original author and source are credited.

\section{Introduction}

The population of majority of wildlife species are declining; some are endangered while few species are already extinct predominantly due to illegal hunting, poaching, habitat destruction and other factors. In order to keep a check on dwindling wildlife species, majority of faunal diversity has been protected under different legislations at national as well as international level. In India, most of the species are protected under the Wildlife (Protection) Act, 1972 of India (WPA), which further includes different Schedules and articles based on level of crime committed. While species which are internationally traded, are monitored by regulations of Convention on International Trade in Endangered Species of Wild Fauna and Flora (CITES). In order to strictly enforce WPA, it is necessary to establish a standardize protocol for the identification of species and provide a viable scientific evidence to prove the conviction of crime by offenders [1]. Wildlife crime involves a spectrum of evidence ranging from blood, skin, hairs, tissue/meat, bones, antlers, claws, canines, ivory and miscellaneous wildlife parts and products which may be in finished form. Identification of species from biological samples is an important aspect in wildlife forensics. Some of the evidences like Skin, hairs, antlers etc when intact can be identified using simple microscopic and morphometric techniques and are cost effective. But sample if degraded or processed or other sample like, finished wildlife products, urine, saliva, formalin preserved samples, tanned skins etc requires robust techniques over microscopy and morphology to identifying the species. $[2,3]$.

DNA based species identification relies on successful isolation of genomic DNA from the evidence samples and most of the time, samples sent for forensic DNA examination are degraded or very low in quantity. That affects the efficacy of DNA extraction and PCR amplification of mitochondrial genes. In some cases, samples are preserved in formalin which affects DNA isolation due to forming chemical structures. Formalin preserved samples; the tissue gradually gets a waxy coating of formalin and eventually fixed the tissue sample which in turn inhibit DNA extraction process and it effect negatively to the DNA isolation. $[4,5,6]$. Therefore DNA extraction from the formalin preserved samples is challenging to deal with species identification in wildlife forensic.

Selection of the molecular marker that show variation among the species but conserve within the species group is another important factor for DNA based species identification. So mitochondrial region specific, cytochrome b (Cyt b), 12S ribosomal RNA (12S rRNA), 16S ribosomal RNA (16S rRNA) and cytochrome oxidase subunit I (COI) are commonly used in species identification $[7,8,9]$. Mitochondrial genes have specific characteristics as compared to the nuclear gene because there is no recombination in mtDNA, high copy number in cell and show maternally inheritance $[10]$.

\section{Case History}

This study describe the species identification from three Seizures: Seizure1 consisted of a meat sample suspected to be of hog deer and confiscated from a person in core area of the forest but was preserved in formalin; Seizure 2 contained a small piece of semi cooked meat around ca.100 gms, confiscated by police department in the peripheral area of a National park. The sample that we received was highly degraded and indicated a delay in forwarding the sample. Based on statement by accused, it was inferred that meat was of Nilgai and meant for local consumption. But to prove the commission of crime, legal report was required and 
hence the sample was seized. Seizure 3 included a bone sample seized from a leather bag of a person roaming nearby the buffer zone of a National Park with inadequate morphological features to establish the clear identity but preliminary suspected to be of Sambar based on partial bone fragments.

All seizures consisted of suspected deer species and are strictly prohibited for the commercial utilization under the International Union for the Conservation of Nature and Natural Resources (IUCN) and are protected under schedule III of the Indian Wildlife (Protection Act, 1972) [11]. Since the identity of confiscated samples was objectionable as per legal system in India, authentic identification of all samples is required to prove the accused as an offender. So the samples were forwarded for the analysis from respective enforcement agencies to Wildlife Forensic Cell, Wildlife Institute of India.

\section{Material and Methods}

\section{DNA extraction}

In wildlife forensic, extraction of genomic DNA from the degraded sample is very typical and most important step for the case sample. To carry out the genomic DNA extraction from formalin preserved sample (Seizure 1) we used protocol that was described by Diaz-Cano and Brady, 1997 [12] with some modification. We gave a treatment of PBS solution for two days and then followed the protocol as depicted in earlier studies (Diaz-Cano and Brady, 1997). Seizure 2 was processed with Qiagen DNeasy Tissue Kit (QIAGEN, Germany) as per manufacturer's recommendations and Seizure 3, DNA was extracted using commercially available bone extraction kit $\left(\mathrm{GeNei}^{\mathrm{TM}}\right)$.

\section{PCR amplification}

A fragment of the12S rRNA gene ( $C a .420 \mathrm{bp})$ and Cytb gene ( $\mathrm{Ca}$ $.350 \mathrm{bp}$ ) were amplified using the universal PCR primers (Kocher et al.1989; Mayer, et al., 1995) [7,8]. All PCR reactions were carried out on an Applied Biosystems ${ }^{\circledR} 2720$ Thermal Cycler in a total reaction volume of $20 \mu \mathrm{l}$ containing 1x PCR buffer; $25 \mathrm{mM}$
$\mathrm{MgCl}_{2}, 10 \mathrm{mM}$ dNTPs, $10 \mu \mathrm{M}$ of each primer, $2.5 \mathrm{U}$ Taq polymerase (MBI, Fermentas) and $2 \mu$ of total DNA. The PCR cycle consisted of following steps: initial denaturation at $94^{\circ} \mathrm{C}$ for 5 min, followed by 32 cycles of denaturation at $94^{\circ} \mathrm{C}$ for $35 \mathrm{sec}-$ onds, primer annealing at $53^{\circ} \mathrm{C}$ for 45 seconds, primer extension at $72^{\circ} \mathrm{C}$ for 35 seconds, and a final extension at $72^{\circ} \mathrm{C}$ for $10 \mathrm{~min}$. The PCR products obtained were then subjected to electrophoresis on $2 \%$ agarose gel and visualized over an UV transilluminator to assess amplification. Duplicates, negative and positive controls were performed in DNA extractions and PCR amplifications.

\section{Sequencing}

PCR forward primer (Cytb 381, L-5'-GCCCCTCAGAATGATATTTGTCCTCA-3'), and (12S rRNA Fwd 5'-AAAAAGCTTCAAACTGGGAT'TAGATACCCCACTAT-3) gene were used for the sequencing reactions using the Big Dye ${ }^{\circledR}$ Terminator v3.1 Cycle Sequencing kit (Applied Biosystem). Sequencing reaction products were purified using a standard ethanol-isopropanol precipitation method and sequenced on an ABI 3130 Genetic Analyzer (Applied Biosystem, USA).

\section{Data analysis}

Quality of sequences was determined using Sequence Analysis v 5.2 software (Applied Biosystem) and validated by Sequencher v 4.7 software (www.genecode.com). Additional Multiple Sequence Alignments (MSA) was performed using the CLUSTAL W algorithm implemented in BIOEDIT version 7.0.5.3 [13].

The sequences obtained from the three different specimens were compared with sequences available on public domain at GenBank (http://blast.ncbi.nlm.nih.gov/) using BLAST. Phylogenetic trees including all the aligned sequences were generated based on Kimura 2 parameter distance matrix for Cyt b using the neighbour-joining method as implemented in Mega v 5.1 software [14].

\section{Results and Discussion}

Seizure 1 and Seizure 2 yield good quality of genomic DNA while

Figure 1. Siezure image of (A).Seizure .1, (B). Seizure 2 and (C) Seizure 3.

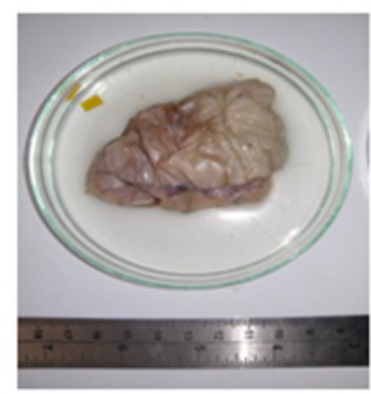

A

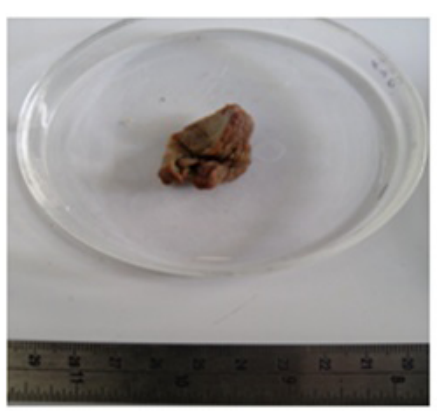

B

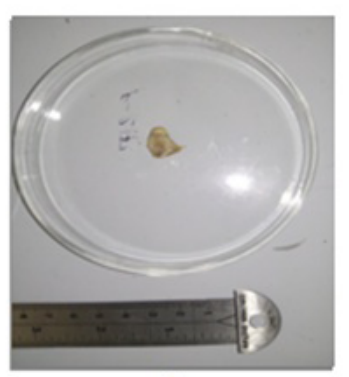

C 
Figure 2. DNA Image of seizure

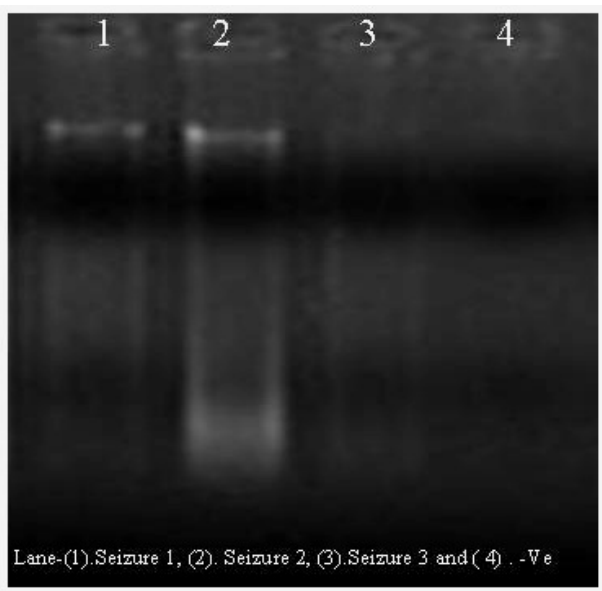

Figure 3. PCR amplification of cytochrome b gene and 12S rRNA (with seizures and positive sample) Lane-1 to 3 (PCR product of cytochrome b gene),Lane-01 to 08 (PCR product of 12SrRNA), Lane-04 and 09 (positive samples), Lane- 05 and 11 (negative control) and Lane-10 (DNA Ladder 100bp).

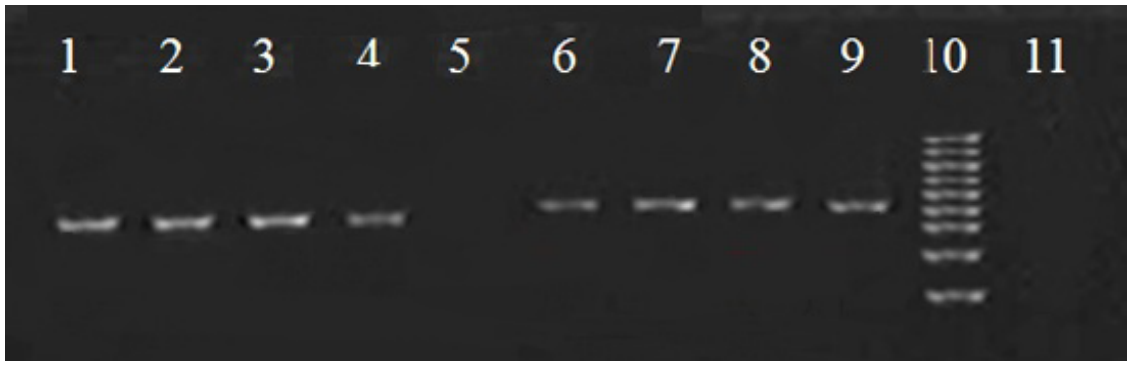

Table 1. Details of used species and GenBank Accretions number of used Cytochrome b and 12S ribosomal RNA.

\begin{tabular}{|l|l|l|l|}
\hline Species & Common name & \multicolumn{2}{|l|}{ GenBank Accession number } \\
\hline & & Cytb & 12S rRNA \\
\hline Axis axis & Chital & $\begin{array}{l}\text { JN093090.1, } \\
\text { N093092.1 }\end{array}$ & $\begin{array}{l}\text { JN093077.1 } \\
\text { JN093073.1 }\end{array}$ \\
\hline Axis porcinus & Hog deer & $\begin{array}{l}\text { EF579805.1, } \\
\text { EF491204.1 }\end{array}$ & $\begin{array}{l}\text { AY775785.1 } \\
\text { AY184435.1 }\end{array}$ \\
\hline Cervus unicolor & Sambar & JN861032.1 & \\
\hline Rucervus duvaucelii & Swamp deer & EF079830.1 & EU908275.1 \\
& & EU084669.1 \\
\hline Muntiacus muntjak & Barking deer & JQ991600.1 & AF294731.1 \\
\hline Antelope cervicapra & Black buck & AF022058.1 & EF175739.1 \\
\hline Tetracerus quadricornis & Four horned antelope & AF036274.1 & EF133853.1 \\
\hline Gazella bennettii & Chinkara & N410357.1 & EF219403.1 \\
\hline Bos gaurus & Gaur & AB077316.1 & AY736583.1 \\
\hline Panthera tigris & Tiger & KC879297.1 & M86494.1 \\
\hline Boselaphus tragocamelus & Nilgai & EF536350.1 & DQ102371.1 \\
\hline Canis aureus & Jackal & AF028138.1 & \\
\hline
\end{tabular}

Table 2. Similarities in the Cytb locus between Seizure 1,Seizure 2 and Seizure 3 and sequences of most similar deer species Hog deer, Chital and Swamp deer available in GenBank.

\begin{tabular}{|l|l|l|l|}
\hline Specimen & $\begin{array}{l}\text { Species with the highest similarity } \\
\text { (GenBank accession in Table 1.) }\end{array}$ & $\begin{array}{l}\text { Query coverage } \\
\mathbf{( \% )}\end{array}$ & $\begin{array}{l}\text { Similarity } \\
\mathbf{( \% )}\end{array}$ \\
\hline Seizure 1 & Hog deer (Axis porcinus) & 100.0 & 100.0 \\
\hline Seizure 2 & Chital (Axis axis) & 100.0 & 100.0 \\
\hline Seizure 3 & Swamp deer (Rucervus duvancelii) & 100.0 & 100.0 \\
\hline
\end{tabular}

Table 3.Similarities in the12S rRNA locus between Seizure 1, Seizure 2 and Seizure 3 and sequences of most similar deer species Hog deer, Chital and Swamp deer available in GenBank.

\begin{tabular}{|l|l|l|l|}
\hline Specimen & $\begin{array}{l}\text { Species with the highest similarity } \\
\text { (GenBank accession in Table 1.) }\end{array}$ & $\begin{array}{l}\text { Query coverage } \\
\mathbf{( \% )}\end{array}$ & $\begin{array}{l}\text { Similarity } \\
\mathbf{( \% )}\end{array}$ \\
\hline Seizure 1 & Hog deer (Axis porcinus) & 100.0 & 99.0 \\
\hline Seizure 2 & Chital (Axis axis) & 100.0 & 99.0 \\
\hline Seizure 3 & Swamp deer (Rucervus duvaucelii) & 100.0 & 100.0 \\
\hline
\end{tabular}


Figure 4. Cytochrome b Neighbour-joining phylogenetic tree showing the relationships of Seizure 1, Seizure 2 and Seizure 3 with the other species

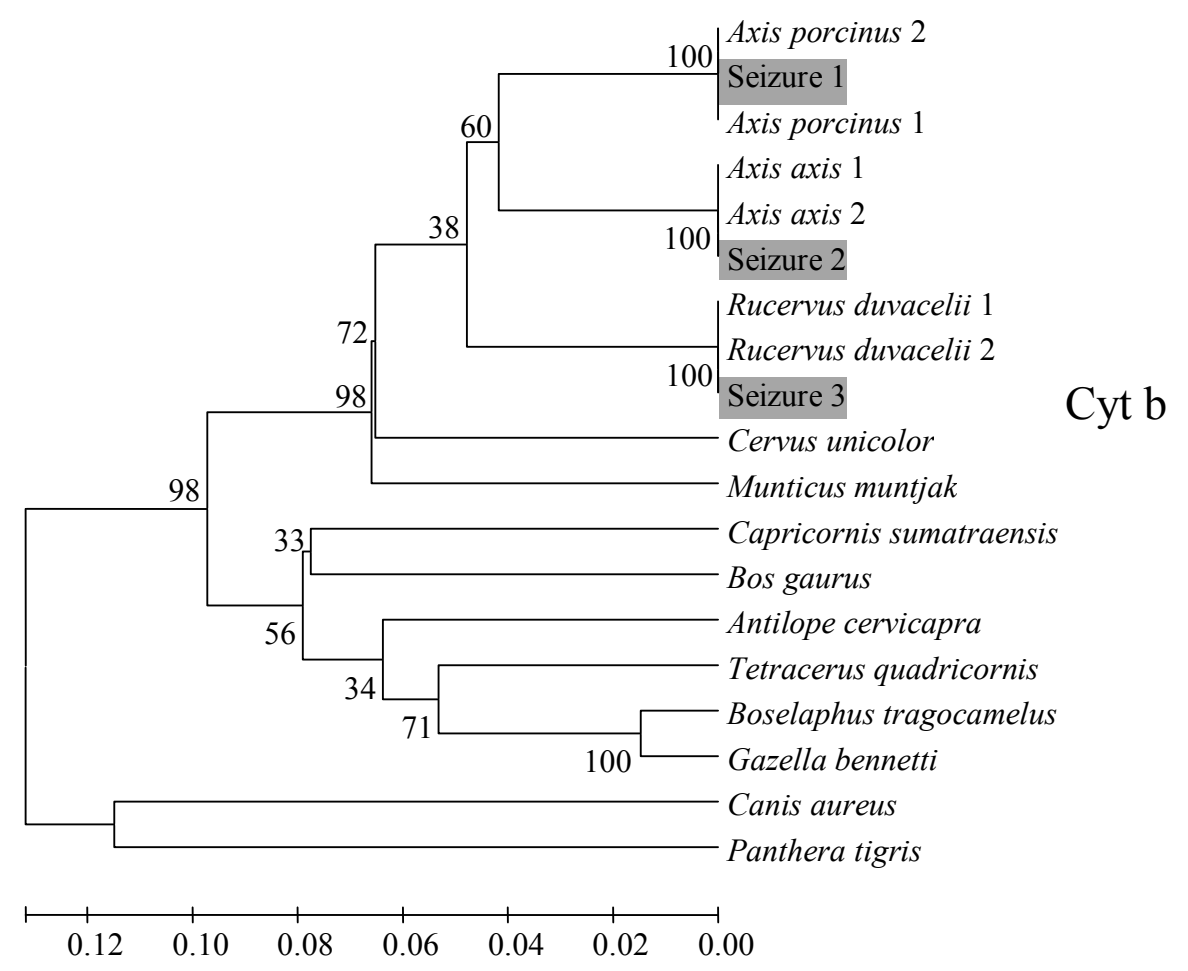

Figure 5. 12S rRNA Neighbor-joining phylogenetic tree showing the relationships of Seizure 1, Seizure 2 and Seizure 3 with the other species.

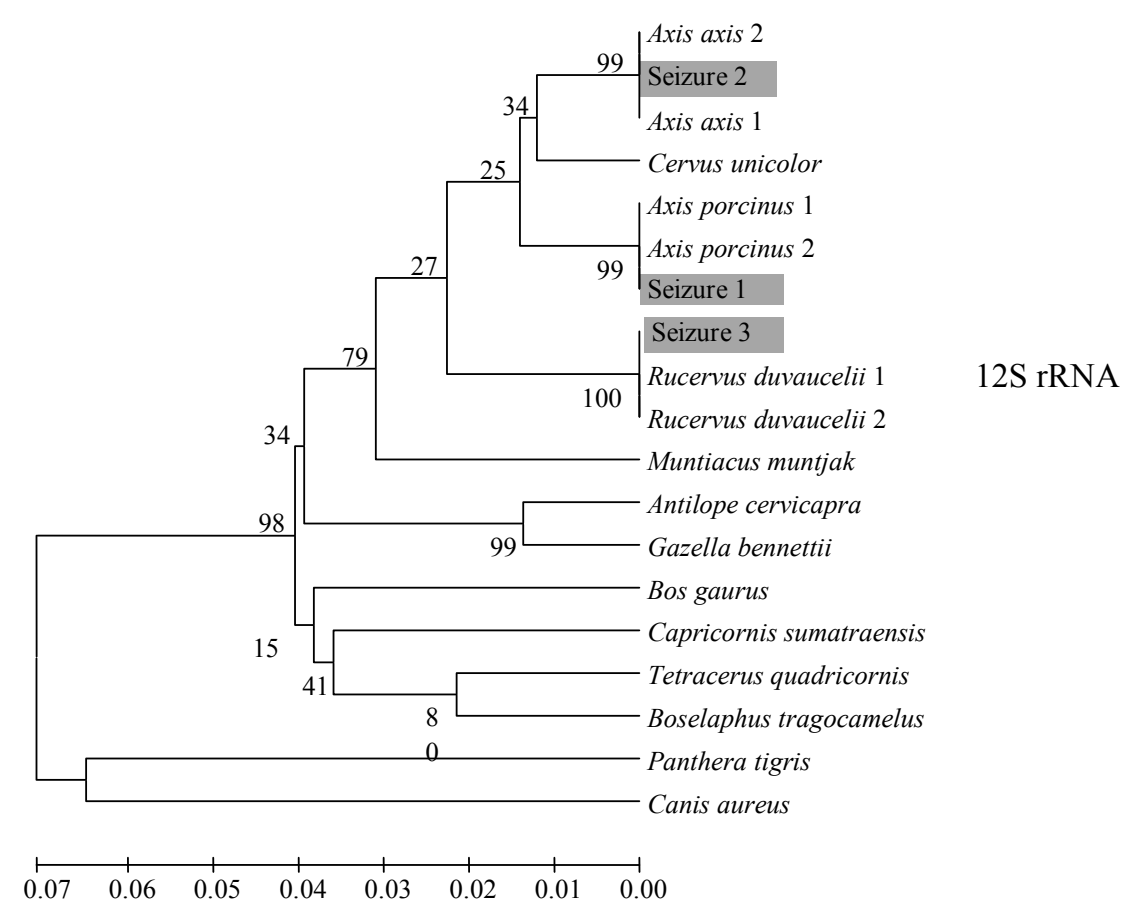

Seizure 3 yielded poor quality of genomic DNA. (Fig. $1 \& 2$ ). All three samples were amplified with both mitochondrial gene (Fig. 3). The sequences obtained were submitted as independent entries in a BLAST search for the most similar sequences using the default MEGA blast algorithm parameters. For the species diagnosis, we considered the percentage similarity between query and reference sequence pairs. The sequences of the seized samples were compared against those of species that were likely to be hunted or consumed at the seizure region (Table 1), which were downloaded from GenBank and available. We used self gener- ated reference sequences of different species those are highly in wildlife trades and available at Wildlife Institute of India. The Cyt b sequencing of used seizures (Seizure 1, Seizure 2 and Seizure 3) produced readable sequences of $C a .350 \mathrm{bp}$ and $C a .420 \mathrm{bp}$. BLAST analysis of Cyt $\mathrm{b}$ indicated that the Seizure 1 was highly similar $(100 \%)$ to the Hog deer (Axis porcinus) with reference sequence, the Seizure 2 was similar $(100 \%)$ to Chital (Axis axis) and the Seizure 3 was similar $(100 \%)$ to swamp deer (Rucervus $d u$ vaucelii). Similar results were found in the $12 \mathrm{~S}$ rRNA gene (Table 2 and Table 3). The neighbor-joining phylogenetic tree showed that 
BLAST analysis and neighbor-joining bootstrap values are similar in three deer species in cytochrome $\mathrm{b}$ gene but in $12 \mathrm{~S}$ rRNA neighbour-joining bootstrap values are different in two deer species (Seizure 1 and Seizure 2) showed 99\% similarity (Fig 4 and Fig 5).

The study reveals that deer species are in demand and soft target for poachers mainly because of their demand for local consumption as well as for antlers, skin and bones as a trophy materials. Hence the population of deer species is declining dramatically. Cyt b gene was effectively used for the identification of species in degraded samples as well as formalin preserved samples. Chital, hog deer and Swamp deer species were identified using molecular forensics techniques, where the morphometric traits are absent and this ultimately proved the commission of crime and offenders were penalized under Wildlife Protection Act, (1972) of India. Future trend relies on use of universal primers that can produce amplification of spectrum of species and ultimately detect Forensically Informative Nucleotide Sequences (FINS) in closely related organisms. Rampant use of Molecular Forensic techniques would help enforcement agencies for effectively controlling poaching and in better wildlife conservation.

\section{Acknowledgments}

The authors are thankful to the Director, Dean and Research CoordinaterWildlife Institute of India (WII), Dehradun, for their strong support.We would like to thank all the researchers and staff of the Wildlife Forensic Cell, WII for providing scientific and technical assistance while undertaking the work.

\section{References}

[1]. Ogden R, Dawnay N, McEwing R(1999) Wildlife DNA forensics-bridging the gap between conservation genetics and law enforcement. Endang. Spec. Res. 9.179-195.

[2]. Sahajpal.V and Goyal. SP (2010) Identification of a forensic case using microscopy and forensically informative nucleotide sequencing (FINS): A case study of small Indian civet (Viverricula indica), Science and Justice, 50 94-97; doi:10.1016/j.scijus.2009.07.002.

[3]. Steroid B, Fisher RA, Khan IM, Kessling AM, Archard LC,et al.(1995) Conserved gene sequences for species identification: PCR analysis of the 3' UTR of the SON gene distinguishes human and other mammalian DNAs. Forensic Sci Int 73:171-8.

[4]. Chaw YFM, Crane LE, Lange P, Shapiro R,(1980) Isolation and identification of cross-links from formaldehyde-treated nucleic acids. Biochemistry $19,5525-5531$.

[5]. Paabo S, Higuchi RG, Wilson AC,(1989) Ancient DNA and the polymerase chain reaction: the emerging field of molecular archaeology. J. Biol. Chem. $264,9709-9712$.

[6]. Kosel S, Graeber MB,(1994) Use of neuropathological tissue for molecular genetic studies: parameters affecting DNA extraction and polymerase chain reaction. Acta Neuro pathol. 88,19-25.

[7]. Kocher TD, Thomas WK, Meyer A, Edwards SV, Paabo S,et al.(1989)Dynamics of Mitochondrial DNA Evolution in Animals: Amplification and Sequencing with Conserved Primers. Proceeding of National Academy of Sciences, United States of America, 86,6196-6200.

[8]. Meyer A(1994) Shortcomings of the cytochrome b gene as a molecular marker. Trend Ecol Evol 9(8):278-280.

[9]. Mitchell SE, Cockburn AF and Seawright JA(1993) The mitochondrial genome of Anopheles quadrimaculatus species A: complete nucleotide and organization, Genome 36 1058-1073.

[10]. Arnason U, Adegoke JA, Bodin K, Born EW, Esa YB, et al.(2002) Mammalian mitogenomic relationships and the root of the eutherian tree. Proc. Natl. Acad. Sci., USA.99,8151-8156.

[11]. Sankar K and Acarya B,(2004) Chital (Axis axis (Erxleben,1777).ENVIS Bullietin(Wildlife Institute of India, Dehra Dun) 7.171-180.

[12]. Diaz-Cano SJ, Brady SP,(1997) DNA extraction from formalin fixed, paraffin-embedded tissues: protein digestion as a limiting step for retrieval of high-quality DNA. Diagn. Mol. Pathol. 6,342-345.

[13]. Hall TA,(1999) BioEdit: a user-friendly biological sequence alignment editor and analysis program for windows 95/98/NT. Nucleic Acids Symposium Series. $41,95-98$.

[14]. Tamura K, Peterson D, Peterson N, Stecher G, Nei M, et al. (2011) Molecular Evolutionary Genetics Analysis using Maximum Likelihood, Evolutionary Distance, and Maximum Parsimony Methods. Mol. Biol. Evol. 28,2731-2739. 